\title{
OBSERVATIONS ON THE VOLUME OF DISTRIBUTION OF INULIN IN ANURIC SUBJECTS ${ }^{1}$
}

\author{
By JOHN T. FINKENSTAEDT, MAURICE P. O'MEARA, AND JOHN P. MERRILL 2 \\ (From the Department of Medicine, Harvard Medical School and Medical Service, Peter Bent \\ Brigham Hospital, Boston, Mass.)
}

(Submitted for publication September 26, 1952; accepted December 10, 1952)

Previous studies (1-5) on normal rats, dogs, and humans suggested that inulin was not metabolized, and that it provided an accurate and reproducible measure of some fixed volume of body fluid, presumably the extracellular fluid. This was established on the basis of : (1) virtually complete urinary recovery of inulin after infusion (1, 5 ) ; and (2) uniform distribution after 2 hours in dogs and 5 hours in man even though infusions were run for as long as 12 hours in the dog and 20.5 hours in man (1). In the absence of renal excretion, it was assumed that at equilibrium inulin would be distributed in a constant volume, and since it suffered no metabolic degradation it would afford a reasonably constant reference for changes in this volume. The present study was undertaken in an attempt to assess this premise.

\section{METHODS}

Purified inulin prepared by U. S. Standard Products Company was used. The various lots of inulin used were tested for fructose content by yeasting so that the actual amount of inulin injected could be accurately assessed. Inulin determinations on sera and urines were performed by Schreiner's modification of Roe's method (6), using venous sera in patients and arterial sera in dogs, and precipitating protein by the cadmium sulfate technique. Blood sugar determinations were done on all subjects, the highest noted being $191 \mathrm{mgm}$. per cent with the great majority under $120 \mathrm{mgm}$. per cent. In this laboratory, standard glucose solutions of 100 and $200 \mathrm{mgm}$. per cent develop color equivalent to 1.17 and $2.23 \mathrm{mgm}$. per cent of inulin respectively. Hence, yeasting was thought unnecessary.

\section{Human studies}

The 13 patients included in this study all had acute anuria of the "lower nephron nephrosis" type, with a

1 This work was supported in part by grants from the Office of the Surgeon General, U. S. Army, under contract No. W-49-007-MD-497 and in part by grants from the National Heart Institute, U. S. Public Health Service, and from the American Heart Association.

2 Established Investigator, American Heart Association. variety of causes as listed in Table I. They were oliguric (urine volume less than $100 \mathrm{ml}$. per $24 \mathrm{hr}$ ) from 2 to 10 days (average 7.4) before inulin was given. One intravenous injection of inulin was given, with the dose ranging from 4.2 to $13.6 \mathrm{gm}$. (average $7.3 \mathrm{gm}$.). The larger doses were administered later in the study in order that the higher serum levels obtained would minimize the effect of a rising serum inulinoid blank. In 2 patients, doses of inulin were also given 40 and 68 hours after the first dose.

All patients were on a regime of strict fluid restriction (500 to $800 \mathrm{ml}$. per day). During the 8 to 96 hours that serum inulin levels were followed, 7 patients lost an average of $1.1 \mathrm{~kg}$. of body weight; 3 gained an average of $0.9 \mathrm{~kg}$. ; 2 had no change in weight; and 2 did not have second weighings.

In all cases, serum inulinoid blanks were determined prior to injecting inulin. Serial venous samples were obtained at varying intervals for 8 to 96 hours after injection. All urines were collected and analyzed for inulin; in 10 of 13 patients the volume of urine amounted to less than $100 \mathrm{ml}$. in the 24 hours after injection.

The apparent volume of distribution of inulin at any given time was calculated by dividing the amount administered (I), less the amount excreted in the urine (U),

TABLE I

Cause, duration and weight change of oliguria in human subjects

\begin{tabular}{|c|c|c|c|}
\hline Pt. & Diagnosis & $\begin{array}{l}\text { Days of } \\
\text { oliguriat }\end{array}$ & $\begin{array}{l}\text { Weight } \\
\text { change } \\
\text { in kg. }\end{array}$ \\
\hline E. B. & $\begin{array}{l}\text { Sulfa, ? Shock } \\
\text { Infectious Hepatitis }\end{array}$ & 5 & 0 \\
\hline $\begin{array}{l}\text { C. G. } \\
\text { D. T. }\end{array}$ & $\begin{array}{l}\text { Acute Yellow Atrophy } \\
\mathrm{HgCl}_{2} \text { Intox. } \\
\text { Prem. Sep. Placenta }\end{array}$ & $\begin{array}{l}6 \\
8\end{array}$ & $\begin{array}{l}0 \\
+0.4\end{array}$ \\
\hline $\begin{array}{l}\text { A. W. } \\
\text { C. C. } \\
\text { R. A. } \\
\text { C. I. } \\
\text { M. R. } \\
\text { A. S. } \\
\text { D. B. }\end{array}$ & $\begin{array}{l}\text { Bilat. Cortical Necr. } \\
\text { Op. Shock-? Tx* } \\
\text { Tx*-Bleeding Ulcer } \\
\text { Tx*-Incompl. Abortion } \\
\text { Tx*-Postpartum } \\
\text { Meningitis-? Shock } \\
\text { Idio. Myoglobinuria } \\
\text { ? Induced Abortion, } \\
\text { Intravasc. Hemolysis }\end{array}$ & $\begin{array}{l}8 \\
6 \\
9 \\
8 \\
9 \\
9 \\
7 \\
5\end{array}$ & $\begin{array}{c}-2.7 \\
-1.0 \\
-0.8 \\
-1.2 \\
-0.2 \\
? \\
+1.6 \\
0\end{array}$ \\
\hline $\begin{array}{l}\text { E. B. } \\
\text { P. Mc. }\end{array}$ & $\begin{array}{l}\mathrm{CCl} \text {. Intox. } \\
\mathrm{Tx}^{*} \text {-Postpartum }\end{array}$ & $\begin{array}{r}10 \\
2\end{array}$ & $\begin{array}{l}+0.8 \\
-0.6\end{array}$ \\
\hline
\end{tabular}

$* T x=$ Transfusion Reaction

$\dagger$ Less than $100 \mathrm{ml}$. urine per day (before inulin)

* During Inulin Study 
by the serum inulin level (C) less the pre-injection blank (B) i.e., $V=\frac{I-U}{C-B}$. This volume then was expressed as a percentage of the body weight at time zero. Spaces were calculated at $8,24,48,72$, and 96 hours after injection, in cases in which it was possible to continue the study.

Inulin could not be detected in any significant amount in vomitus or feces, after preparing protein-free filtrates and performing determinations by the same methods as used for blood and urine. Urinary recovery of inulin during the post-oliguric diuresis was inaccurate because the amount excreted was masked by the high urinary inulinoid blank values.

Urinary inulinoid blank values were studied in several patients who did not receive inulin; these varied from 11 to 32 mgm. per cent.

\section{Animal experiments}

Studies were performed on 6 bilaterally nephrectomized dogs. Two were used to study the increase of inulinoid blank values alone as uremia progressed. In the other 4 dogs, which lived 7 or more days, a single intravenous dose of inulin was given 20 hours after nephrectomy; the dosage used was $0.2 \mathrm{gm}$. per $\mathrm{kg}$. in $1 \mathrm{dog}, 1.0 \mathrm{gm}$. per $\mathrm{kg}$. in 3. These animals were given daily vitamins, antibiotics, and intravenous hypertonic glucose. They received nothing by mouth. Four dogs did not vomit until the fifth day or later; 2 others vomited less than $50 \mathrm{ml}$. daily before the fifth day. One animal had severe diarrhea. Fluid was restricted to permit an average weight loss of approximately $0.1 \mathrm{~kg}$. daily. The initial weights of all dogs approximated $20 \mathrm{~kg}$. Arterial serum samples were used for analysis; otherwise, spaces were determined and calculated as for the patients.

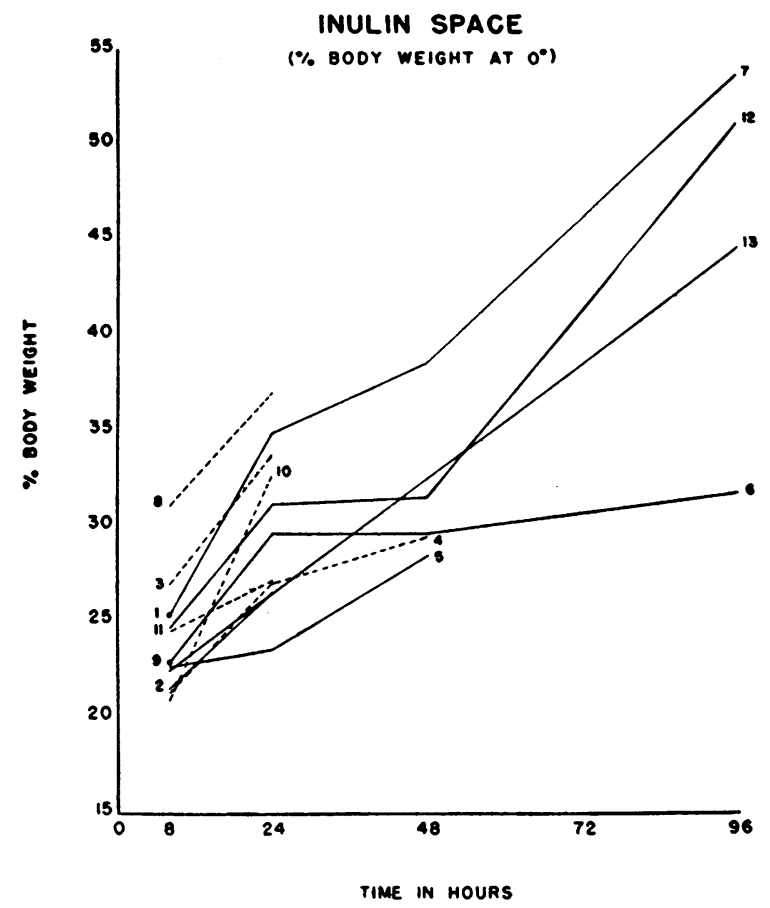

FIG. 1

\section{RESULTS}

The apparent volume of distribution of inulin ("inulin space") in patients at 8 hours averaged 24 per cent of body weight (20.8 to 31.0 per cent). Twenty-four hour spaces in 10 patients averaged

TABLE II

Inulin spaces in anuric patients*

\begin{tabular}{|c|c|c|c|c|c|c|c|c|c|c|}
\hline \multirow{3}{*}{ Pt. } & \multirow{2}{*}{ Wt. } & \multirow{2}{*}{$\underset{\text { dose }}{\text { Inulin }}$} & \multicolumn{2}{|c|}{$8 \mathrm{Hr}$. } & \multicolumn{2}{|c|}{$24 \mathrm{Hr}$. } & \multicolumn{2}{|c|}{$48 \mathrm{Hr}}$. & \multicolumn{2}{|c|}{$96 \mathrm{Hr}$. } \\
\hline & & & $\begin{array}{l}\text { Serum } \\
\text { level }\end{array}$ & Space & $\begin{array}{l}\text { Serum } \\
\text { level }\end{array}$ & Space & $\begin{array}{c}\text { Serum } \\
\text { level }\end{array}$ & Space & $\begin{array}{c}\text { Serum } \\
\text { level }\end{array}$ & Space \\
\hline & $\mathbf{K} \mathbf{g}$ & Gm. & $\begin{array}{l}\text { Mgm./ } \\
100 \mathrm{ml}\end{array}$ & \% Wt. & $\begin{array}{l}\mathrm{Mgm} . / \\
100 \mathrm{ml}\end{array}$ & $\% \mathrm{Wt}$. & $\begin{array}{l}\text { Mgm.f } \\
100 \mathrm{ml} .\end{array}$ & \% Wt. & $\begin{array}{l}\text { Mgm.l } \\
100 \mathrm{ml} .\end{array}$ & \% Wt. \\
\hline $\begin{array}{l}\text { A. W. } \\
\text { E. B. } \\
\text { C. I. } \\
\text { C. C. } \\
\text { C. G. } \\
\text { D. T. } \\
\text { R. A. } \\
\text { A. S. } \\
\text { M. R. } \\
\text { J. D. } \\
\text { D. B. } \\
\text { E. B. } \\
\text { P. Mc. }\end{array}$ & $\begin{array}{l}96 \\
71 \\
64 \\
73 \\
74 \\
51.2 \\
57.8 \\
85.0 \\
58.4 \\
73 \\
84 \\
58 \\
70.2\end{array}$ & $\begin{array}{r}4.4 \\
4.4 \\
4.2 \\
4.4 \\
4.4 \\
4.4 \\
4.2 \\
7.3 \\
9.0 \\
9.7 \\
9.9 \\
9.7 \\
13.6\end{array}$ & $\begin{array}{l}21.6 \\
24.5 \\
25.3 \\
26.7 \\
29.0 \\
32.0 \\
32.0 \\
37.8 \\
49.8 \\
54.4 \\
56.8 \\
68.0 \\
86.4\end{array}$ & $\begin{array}{l}21.2 \\
25.3 \\
25.3 \\
22.6 \\
21.5 \\
26.9 \\
22.7 \\
22.7 \\
31.0 \\
24.4 \\
20.8 \\
24.6 \\
22.5\end{array}$ & $\begin{array}{l}17.0 \\
17.0 \\
25.6 \\
22.2 \\
25.0 \\
24.0 \\
41.7 \\
48.2 \\
36.2 \\
52.3\end{array}$ & $\begin{array}{l}27.0 \\
34.9 \\
23.5 \\
26.5 \\
33.6 \\
29.6 \\
37.0 \\
27.1 \\
32.6 \\
30.7\end{array}$ & $\begin{array}{l}15.6 \\
13.7 \\
21.0 \\
23.0\end{array}$ & $\begin{array}{l}29.4 \\
38.6 \\
28.4 \\
\\
29.6\end{array}$ & $\begin{array}{l}26.0 \\
23.0\end{array}$ & $\begin{array}{l}53.6 \\
31.7\end{array}$ \\
\hline \multicolumn{4}{|c|}{$\begin{array}{l}\text { Average } \\
\text { Range }\end{array}$} & $\begin{array}{r}24.0 \% \\
(20.8-31.0)\end{array}$ & & $\begin{array}{r}30.2 \% \\
(23.5-37.0)\end{array}$ & & $\begin{array}{c}31.5 \% \\
(28.4-38.6)\end{array}$ & & $\begin{array}{r}45.2 \% \\
(31.7-53.6)\end{array}$ \\
\hline
\end{tabular}

* Corrected for pre-injection inulinoid blank. 
30.2 per cent (23.5 to 37 per cent). Spaces of 4 patients followed for 96 hours averaged 45.2 per cent ( 32 to 53.6 per cent). The data are shown in Table II and represented graphically in Figure 1.

In 2 of the above patients, repeat space determinations were made at 40 and 68 hours, by giving an additional dose of inulin, correcting for preinjection inulin level and calculating the space at 8 hours after this second injection. In one patient the first measurement was 16.8 liters and on repeating the determination with a second dose of inulin 40 hours later the space was 19.3 liters. In the second patient, the initial measurement was 16 liters and the second measurement 68 hours. later was 17.5 liters. In the first patient the 40 hour "space" calculated from the disappearance curve of the initial inulin was 33 per cent and in the second patient a 68 hour space similarly calculated was 59 per cent.

In an effort to determine the effect of anuria on the serum inulinoid blank, 2 bilaterally nephrectomized dogs were studied for 117 and 164 hours respectively without giving inulin. In each case, there was a gradual and progressive rise in the se- rum blank values from an initial value of 1.7 and $1.5 \mathrm{mgm}$. per cent to $7 \mathrm{mgm}$. per cent at 117 hours and $11.5 \mathrm{mgm}$. per cent at 164 hours.

One bilaterally nephrectomized dog was given inulin in an amount similar to that given patients ( $0.2 \mathrm{gm}$. per kg.). At 2 hours, the serum inulin level, corrected for zero hour blank value, was 95 mgm. per cent with an inulin space of 17 per cent of body weight. At 120 hours, the actual serum level was $16 \mathrm{mgm}$. per cent, but if corrected for the serum blank at 120 hours, as determined in the contrast study, the true serum inulin level approached the serum inulinoid blank value.

To minimize the effect of varying serum blanks, 3 bilaterally nephrectomized dogs were given large doses of inulin ( $1.0 \mathrm{gm}$. per $\mathrm{kg}$.). Initial serum levels ranged from 530 to $600 \mathrm{mgm}$. per cent and the 2 hour spaces were $18,18.4$ and 19 per cent of. body weight. In each instance, there was a gradual and progressive decline in the serum levels, averaging 0.5 per cent of the administered dose per hour.

One animal died at 95 hours with a space of 31 per cent. A second dog's space was 40.5 per cent

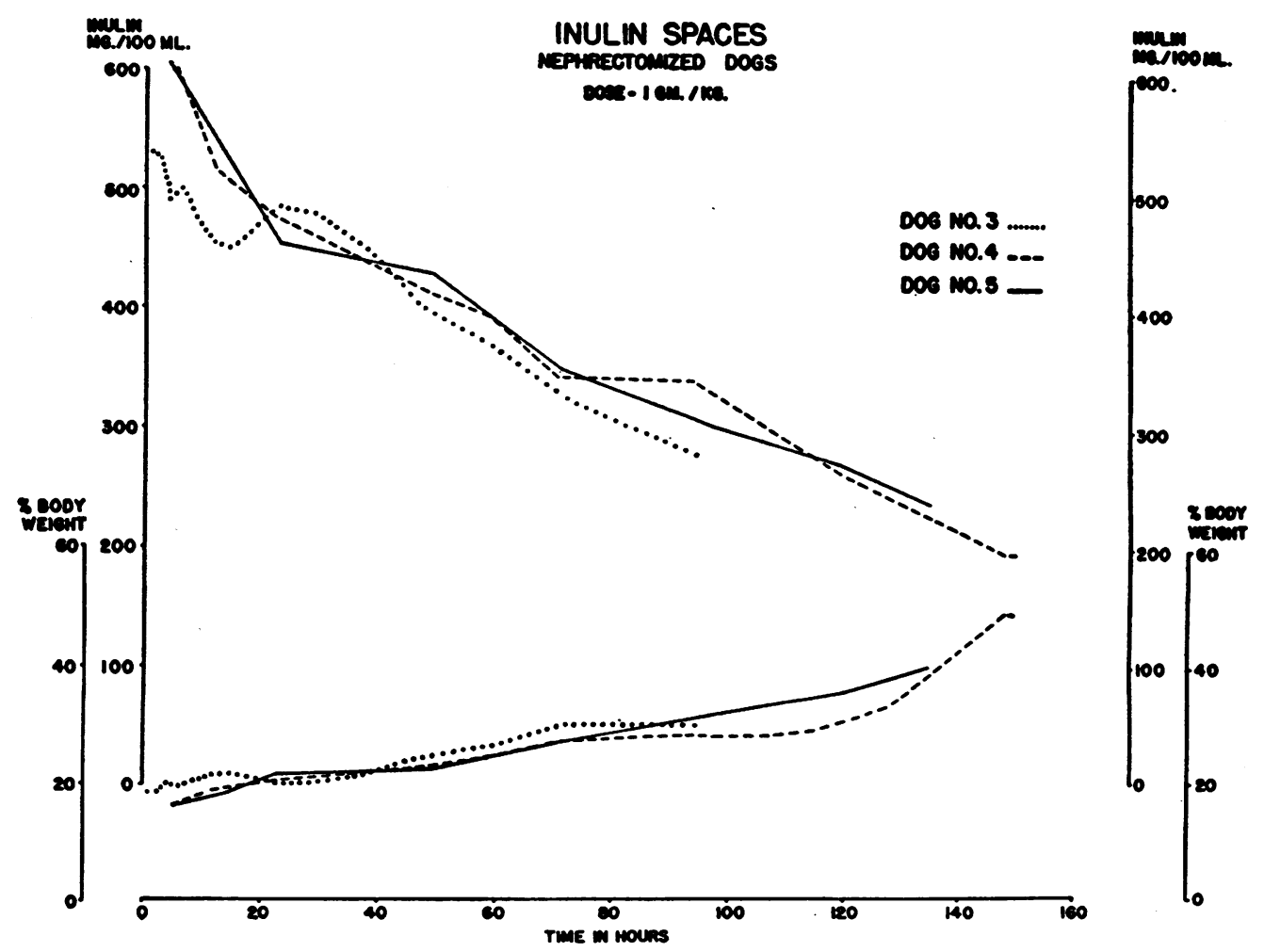

Fre. 2 
at 133 hours and the third showed an "inulin space" of 50 per cent at 150 hours. The results are shown in Figure 2. It is interesting to note that the values for serum levels and inulin spaces are virtually identical in all 3 animals, particularly since one dog had severe diarrhea and the others did not. In this case, loss was carefully measured and replaced by intravenous fluids.

In order to exclude the possibility of inhibiting substances in uremic serum, known amounts of inulin were added to the serum of both humans and dogs and allowed to incubate at body temperature under sterile conditions for varying periods up to 24 hours. Recovery was 98 to 101 per cent in all tests.

In addition, sera from 4 patients, who received inulin, were analyzed before and after 6 hour runs on the Kolff artificial kidney. In a typical experiment blood urea nitrogen concentration was decreased from values of $313 \mathrm{mgm}$. per $100 \mathrm{ml}$. to $65 \mathrm{mgm}$. per $100 \mathrm{ml}$. with comparable changes in other retained metabolites. Inulin values in the 4 patients decreased 2 to $4.5 \mathrm{mgm}$. per cent. Three patients who had not received inulin were studied in a similar manner. Initial inulinoid blanks varied 2.5 to $4.9 \mathrm{mgm}$. per cent. Values following dialysis were reduced by 2 to $4 \mathrm{mgm}$. per cent. Thus, it appears that the inulinoid blank diffuses through a cellophane membrane whereas inulin does not.

\section{DISCUSSION}

The data presented indicate that inulin does not equilibrate in any fixed volume of body fluid in anuric patients as shown by the steady and continuous fall of inulin levels. That this decrease in inulin concentration could not be accounted for by urinary or other losses or by interference with the determination is suggested by the following:

(1) Total urinary inulin content was small during space studies and urinary inulinoid blank values were high.

(2) Inulin could not be detected in significant amounts in the gastrointestinal contents. The possibility of degradation of inulin in the gastrointestinal tract prior to analysis must be considered, but evidence from experiments on dogs does not support this supposition, since the 3 animals receiving large doses of inulin show practically superimposable curves for both serum inulin concentrations and "inulin spaces." Of these, 2 ani- mals had minimal gastrointestinal losses, while one had severe diarrhea throughout the study, replaced volume for volume by saline. This argues against loss of inulin into the gastrointestinal tract.

(3) Incubation of inulin with uremic (anuric) sera at body temperature for as long as 24 hours did not prevent complete recovery of inulin. Thus, it seems unlikely that interfering substances invalidate the determinations.

The serum inulinoid blank is high in uremia and rises in anuric dogs from initial concentrations of 1 to $3 \mathrm{mgm}$. per cent to as high as $12.5 \mathrm{mgm}$. per cent in our studies. This change is variable in different subjects and cannot be correlated with blood urea levels or other indices of uremia. Glucose contributes to this blank about $1 \mathrm{mgm}$. per cent per $100 \mathrm{mgm}$. per cent glucose. In our series, the glucose levels did not vary greatly and did not become high enough to account for the high blank values observed. The cause of this high inulinoid blank has not been determined. Our observations on patients undergoing hemodialysis indicate that the artificial kidney will remove some substance or substances present in the blood responsible for the elevated blank values in uremia.

When smaller doses of inulin are given $(0.2 \mathrm{gm}$. per kg.), the blank factor becomes very significant after 3 to 4 days of anuria. In the experiments on dogs if the serum inulin levels of one animal are corrected for the blank value observed in another, serum levels approach the blank value between 100 to 160 hours. Therefore, virtually all inulin has disappeared from the serum, indicating an inulin space of nearly 100 per cent of body weight. If large amounts of inulin are administered $(1 \mathrm{gm}$. per $\mathrm{kg}$.), the blank factor becomes insignificant.

The observations relating to this subject made by other workers may be summarized as follows:

(1) Gaudino and Levitt (2) studied 3 bilaterally nephrectomized dogs utilizing a single injection of inulin. They stated that a uniform distribution was obtained in 1 to 2 hours, a period similar to that observed in normal dogs. However, it was noted that the inulin space began to increase after 6 hours. This was attributed to a terminal pathological shift of intracellular water.

(2) Kruhфffer (3) studied 13 nephrectomized rabbits and one nephrectomized dog. In the former, equilibration of inulin had not occurred when followed as long as 10 hours. In the latter, 
the inulin space was still expanding at 12 hours.

(3) Berger and his coworkers (7) measured inulin spaces in 6 nephrectomized dogs. In all animals, a slow and continuous fall in inulin plasma levels was noted, varying from 0.15 to 0.72 per cent per hour (our animals averaged 0.5 per cent per hour). They attributed this to either slow metabolism or changing cellular permeability.

(4) Cotlove (8) analyzed inulin and chloride in rat muscle after infusions of $1,2,6$ and 15 hours. The inulin space showed a progressive approximation to the chloride space with increasing time of infusion.

(5) Nichols and his associates (9) studied 8 dogs after a single injection of inulin. Inulin spaces in muscle showed a continuous increase from 3 to 6 hours. Studies were not carried beyond this period.

Among possible explanations for the observed data, the following are to be considered: (a) a metabolic degradation of inulin, (b) a valid expansion of the extracellular fluid space during anuria, and (c) a shift of inulin into cell, bone, or connective tissue or other body water not included in the "extracellular fluid" as defined in 6 to 8 hour "inulin space" in normal subjects.

A real expansion of extracellular fluid probably does occur in many anuric patients who are overhydrated, but this cannot explain changes of the magnitude observed. The calculated "inulin spaces" in patients reached values as high as 40 to 50 per cent of body weight without clinical evidence of over-hydration. Furthermore, in dogs, which could be followed longer, the "inulin spaces" reached the impossible value of nearly 100 per cent of body weight.

The other possibilities are more difficult to exclude, and additional studies are necessary to determine which is correct. Nichols and associates (9) observed that the inulin space determined by tissue analysis of muscle and connective tissue of anuric animals, gradually increases after an injection of inulin. However, this would not explain the magnitude of change we observed in dogs given large doses of inulin. Because of this, it is probable that destruction of inulin does occur either in the extracellular fluid or after penetration into cells or both. If so, it is possible that there is a similar, slow degradation of inulin in non-anuric subjects which cannot be detected by the methods now employed to measure inulin space. Such a loss is apparent in the data of Gaudino and Levitt (2) although they attribute it to redistribution of fluid.

SUMMARY AND CONCLUSIONS

1. Thirteen patients with acute anuria were studied using a single injection of inulin. A steady and continuous fall of the serum inulin levels and rise in "inulin space" values was observed.

2. A similar phenomenon was noted in bilaterally nephrectomized dogs and could not be explained by changing blank, external losses, dilution or interfering substances.

3. The volume of distribution of inulin as calculated from serum levels after a single dose in the anuric subject shows a progressive increase, the magnitude of which probably indicates a disappearance of the injected inulin rather than a valid increase in "inulin space."

\section{ACKNOWLEDGMENTS}

Marcia D. Liftman for technical assistance and Dr. Roy C. Swan for valuable advice and assistance.

U. S. Standard Products Co. of Woodworth, Wisconsin, for providing the inulin preparation used.

\section{REFERENCES}

1. Gaudino, M., Schwartz, I. L., and Levitt, M. F., Inulin volume of distribution as a measure of extracellular fluid in dog and man. Proc. Soc. Exper. Biol. \& Med., 1948, 68, 507.

2. Gaudino, M., and Levitt, M. F., Inulin space as a measure of extracellular fluid. Am. J. Physiol., 1949, $157,387$.

3. Kruhфffer, P., Inulin as an indicator for the extracellular space. Acta Physiol. Scandinav., 1946, 11, 16.

4. Wilde, W. S., The chloride equilibrium in muscle. Am. J. Physiol., 1945, 143, 666.

5. Shannon, J. A., and Smith, H. W., The excretion of inulin, xylose and urea by normal and phlorizinized man. J. Clin. Invest., 1935, 14, 393.

6. Schreiner, G. E., Determination of inulin by means of resorcinol. Proc. Soc. Exper. Biol. \& Med., 1950, 74, 117.

7. Berger, E. Y., Dunning, M. F., Steele, J. M., Jackenthal, R., and Brodie, B., Estimation of intracellular water in man. Am. J. Physiol., 1950, 162, 318.

8. Cotlove, E., Inulin and chloride space in muscle. Federation Proc., 1952, 11, 28.

9. Nichols, G., Jr., Nichols, N., Weil, W. B., and Wallace, W. M., The direct measurement of the extracellular phase of tissues. J. Clin. Invest., 1952, 31, 652. 